\title{
Sosialisasi Pandemik Covid-19 dan Diseminasi Konsep Kota Cerdas, Sehat, dan Tangguh Pandemik
}

\author{
Yashinta K.D. Sutopo ${ }^{1 *}$, Muh. Yamin Jinca ${ }^{1}$, Ananto Yudono ${ }^{1}$, Mimi Arifin ${ }^{1}$, Abdul Rahman \\ Rasyid $^{1}$, Arifuddin Akil ${ }^{1}$, Mukti Ali ${ }^{1}$, Ihsan Latif ${ }^{1}$, Laode M. Asfan ${ }^{1}$, Azizah Putri Abdi ${ }^{1}$ \\ Departemen Perencanaan Wilayah dan Kota, Fakultas Teknik Universitas Hasanuddin ${ }^{1}$ \\ Yashintasutopo17@gmail.com*
}

\begin{abstract}
Abstrak
Pandemik Covid-19 yang saat ini melanda Indonesia membutuhkan peran aktif dari semua pihak, termasuk dari institusi Pendidikan. Departemen Perencanaan Wilayah dan Kota (PWK) Universitas Hasanuddin (Unhas) mendukung Pemerintah diantaranya melalui dua kegiatan pengabdian masyarakat sebagai bagian dari pelaksanaan tugas tridarma perguruan tinggi. Kegiatan pertama yaitu sosialisasi informasi mengenai Covid-19 kepada masyarakat melalui pendekatan edukatif, persuasif dan animatif dalam bentuk format tulisan, foto, poster dan video yang diunggah melalui youtube dan instagram pada April dan Mei 2020 dengan target $\pm 1,000$ peninjau (viewers). Kegiatan kedua yaitu diseminasi konsep Kota Cerdas, Sehat, dan Tangguh Pandemik sebagai upaya antisipasi terjadinya pandemik dimasa depan dengan pendekatan ilmiah, sistemis dan kolaboratif dalam bentuk format seminar nasional virtual yang diselenggarakan pada 24 September 2020 dengan target \pm 300 peserta. Makalah ini bertujuan untuk membahas mengenai tujuan, proses, dan hasil dari dua kegiatan tersebut serta memaparkan rangkuman gagasan inti konsep kota yang dipresentasikan dalam kegiatan kedua. Sampai dengan 10 Oktober 2020, tercatat total 4,037 viewers yang mengunjungi media sosial yang digunakan pada kegiatan pertama. Tercatat pula total 1,008 orang tertarik dengan tema yang diusung pada kegiatan kedua dan mendaftar melalui email panitia meski pendaftaran dibuka hanya berselang 7 hari sebelum acara. Total 584 peserta tercatat hadir saat kegiatan kedua berlangsung dimana 42 orang berasal dari 22 dinas pemerintahan dan kementerian, 135 orang dari 46 universitas di luar Sulsel, 10 orang dari 7 wilayah IAP, dan 10 orang dari 6 konsultan/institut perencanaan/arsitektur. Jumlah viewers dan peserta dikedua kegiatan ini yang lebih tinggi dari target yang ditetapkan menunjukkan peran aktif yang optimal dari departemen dalam mendukung Pemerintah dan masyarakat sesuai bidang dan kapasitasnya.
\end{abstract}

Kata Kunci: Pengabdian Masyarakat; Sosialisasi: Kota; Tangguh; Pandemik.

\begin{abstract}
Covid-19, a global pandemic, demands active roles from everyone, including from educational institution. Department of Urban dan Regional Planning of University of Hasanuddin supports the Government and the society by organizing two community service activities as part of three pillars of higher education. The first activity is to advocate and raise public awareness on Covid-19 through educative, persuasive and animative approaches in the form of writings, photos, posters and videos posted via youtube and Instagram on April and May 2020 targeting minimal 1,000 viewers. The second activity is to disseminate concept of smart, healthy and resilient city as a planning effort anticipating for future pandemics through scientific, systemic, and collaborative approaches in the form of a virtual national seminar held on 24 September 2020 targeting minimal 300 participants. This paper aimed to describe the objectives, processes and results of these two activities as well as to enlighten the main ideas of the concept presented in second activity. Up to 10 October 2020, it was noted that a total of 4,037 reviewers have visited the social medias used in the first activity. A total of 1,008 requests entered the registration email of the organizer during 7 days prior to the second activity. A total of 584 participants from various universities, government agencies and planning/architectural consultants attended the second activity. The numbers of viewers and participations in both activities that exceeded the initial targets shows an optimum active role of the department in supporting the Government and the society based on to its field and capacity.
\end{abstract}

Keywords: Community Services; Socialization; City; Resilient; Pandemic. 


\section{Pendahuluan}

Sejak 31 Desember 2019 sampai dengan hari saat ini (24 Sept 2020) sudah 9 bulan atau tepatnya 269 hari penduduk dunia menghadapi Pandemik Covid-19 dan telah terjadi 31,375,325 kasus infeksi dan 966,399 kasus kematian di 235 negara dan wilayah di dunia (www.who.int). Sejak 2 Maret 2020 sampai dengan hari ini, sudah 7 bulan atau tepatnya 207 hari Bangsa Indonesia menghadapi pandemik ini secara maraton dan telah terjadi 257,388 kasus infeksi dan 9,977 kasus kematian (www.covid19.go.id/). Pandemik ini tidak hanya menyebabkan krisis kesehatan dan korban jiwa yang besar, tetapi juga krisis ekonomi, krisis pangan, krisis sosial, krisis keamanan, dan krisis dihampir semua aspek kehidupan lainnya.

Covid-19 bukanlah pandemik pertama yang dihadapi oleh penduduk bumi. Dalam abad ini saja, tercatat 4 pandemik yang generasi ini pernah alami, yaitu: Spanish Flu tahun 1918, Asian Flu tahun 1957, Hongkong Flu tahun 1968, dan Swine Flu tahun 2009. Spanish Flu 1918 yang terjadi baru sekitar 100 tahun yang lalu, bahkan diperkirakan menginfeksi 500 juta orang atau 1/3 dari jumlah penduduk bumi saat itu, dan menyebabkan 50 juta kasus kematian (www.cdc.gov). Ini adalah pandemik yang dianggap sangat mematikan dan meruntuhkan sendi-sendi pembangunan seluruh dunia. Agar dampak negatif pada pandemik yang lalu tidak terjadi pada pandemik hari ini, dibutuhkan dukungan dan peran aktif dari semua pihak dan bidang untuk bergerak sesuai kapasitas dan keahliannya masing-masing.

Dalam bidang perencanaan kota, perubahan gaya hidup masyarakat perkotaan menjadi peka pandemik dan perencanakan kota yang tangguh terhadap pandemik adalah diantara isu yang paling penting untuk dibahas. Kota menjadi fokus utama karena Covid-19 lebih rawan menyebar di kota daripada di desa disebabkan karena kepadatan penduduk dan aktifitasnya yang jauh lebih tinggi dan terkonsentrasi serta pergerakan penduduk dan pengunjungnya yang jauh lebih dinamis dan berskala nasional/internasional. Dominasi sektor jasa juga menjadikan interaksi fisik di perkotaan jauh lebih intens terjadi. Ini sebabnya dua isu tersebut menjadi prioritas sekaligus menjadi tantangan yang harus diinisiasi oleh para perencana kota. Adapun makalah ini bertujuan untuk membahas mengenai kegiatan pengabdian masyarakat dalam kaitannya dengan dua isu tersebut yang telah dilaksanakan oleh Departemen Perencanaan Wilayah dan Kota (PWK) dalam upaya mendukung pemerintah dan masyarakat dalam menghadapi pandemic Covid-19.

\section{Latar Belakang Teori}

Kegiatan pengabdian masyarakat adalah hal yang wajib dilakukan oleh setiap perguruan tinggi (Direktorat Riset dan Pengabdian Masyarakat Kemenristekdikti, 2020). Kegiatan pengabdian masyarakat adalah upaya untuk mengamalkan ilmu pengetahuan dan teknologi untuk mencerdaskan dan meningkatkan kesejahteraan masyarakat (Permendikbud No. 3 Tahun 2020). Diantara tujuan diadakannya pengabdian kepada masyarakat oleh perguruan tinggi adalah memberikan solusi berdasarkan kajian akademik atas kebutuhan, tantangan, atau persoalan yang dihadapi masyarakat, baik secara langsung maupun tidak langsung dengan memanfaatkan keahlian sivitas akademika yang relevan (Undang-undang No. 12 Tahun 2012). Dalam kaitannya dengan pandemik Covid-19, Mendikbud Nadiem Makarim dalam salah satu jumpa persnya menyatakan bahwa kiprah perguruan tinggi sangat dibutuhkan di garda depan dalam menangani dan memitigasi bencana ini, baik melalui kegiatan lapangan maupun daring (www.republika.co.id). 
Adapun isi pengabdian masyarakat dapat berupa rekomendasi kebijakan yang dapat diterapkan langsung oleh masyarakat, dunia usaha, industri, dan/atau pemerintah (Direktorat Riset dan Pengabdian Masyarakat Kemenristekdikti, 2020). Penilaian hasil pengabdian kepada masyarakat dapat diukur melalui: 1) tingkat kepuasan masyarakat, yaitu terjadinya perubahan sikap pada masyarakat sesuai dengan sasaran program, 2) dapat dimanfaatkannya ilmu pengetahuan/teknologi di masyarakat secara berkelanjutan, dan 3) teratasinya masalah sosial dan rekomendasi kebijakan yang dapat dimanfaatkan oleh pemangku kepentingan (idem). Selain itu, diharapkan kegiatan pengabdian masyarakat dapat meningkatkan angka partisipasi dosen, meningkatkan kapasitas pengelolaan penelitian dan pengabdian kepada masyarakat di perguruan tinggi, dan memfungsikan potensi perguruan tinggi dalam menopang daya saing bangsa (idem). Kegiatan pengabdian masyarakat karenanya harus dilakukan dengan standar proses yang terdiri atas perencanaan, pelaksanaan, dan pelaporan kegiatan dan diselenggarakan secara terarah, terukur, dan terprogram (idem).

\section{Metode}

Berdasarkan kajian teori diatas, Departemen PWK Unhas, sesuai dengan bidang keahliannya, melakukan dua kegiatan pengabdian masyarakat, yaitu sosialisasi ke masyarakat umum mengenai pandemik Covid-19 dan diseminasi keilmuan kepada masyarakat kalangan perencanaan dan bidang yang terkait lainnya mengenai perencanaan konsep kota sehat, cerdas dan tangguh pandemik. Kegiatan pertama dilakukan bersama 75 orang mahasiswa prodi S1PWK Unhas angkatan 2017 dengan menggunakan pendekatan edukatif, persuasif, inspiratif, dan animatif dalam bentuk foto, poster dan video yang sebarluaskan melalui media youtube dan Instagram. Kegiatan ini berlangsung sejak Februari hingga Oktober 2020. Tahapan yang dilakukan yaitu: 1) Perencanaan: pembentukan kelompok, koordinasi, dan penentuan tema dan format (Februari); 2) Pelaksanaan: kajian awal data/informasi sekunder, penyusunan materi, diskusi kelas (Maret), dan pengunduhan bahan sosialisasi (April/Mei); dan 3) Monitoring hasil dan pelaporan kegiatan (Oktober). Jumlah pengunjung (viewers) pada situs-situs media yang digunakan menjadi salah satu tolak ukur keberhasilan kegiatan ini: semakin banyak pengunjung, maka semakin luas jangkauan dan semakin besar potensi kemanfaatannya.

Kegiatan kedua dilakukan dalam bentuk seminar nasional dengan menggunakan pendekatan secara ilmiah (yaitu berbasis teori dan konsep keilmuan PWK), sistemis (yaitu mencakup huluhilir perencanaan mencakup fakta lapangan, teori, konsep, kurikulum, dan etika profesi), dan kolaboratif (yaitu melibatkan 5 pemateri yang memiliki spesialisasi keilmuan dalam bidang PWK). Kegiatan ini berlangsung sejak Juli hingga Oktober 2020. Tahapan yang dilakukan yaitu: 1) perencanaan: pembentukan tim panitia, koordinasi internal, penyusunan jadwal (Juli), penyusunan konsep dan bahan promosi acara (Agustus) dan koordinasi external (awal September); 2) Pelaksanaan seminar secara virtual melalui aplikasi zoom dan youtube (24 September); dan 3) Monitoring hasil dan pelaporan kegiatan (Oktober). Jumlah peserta sebelum dan saat acara berlangsung menjadi salah satu tolak ukur keberhasilkan kegiatan ini: semakin banyak peserta dan beragam asalnya, maka semakin luas jangkauan dan semakin besar potensi kemanfaatannya.

Output kegiatan ini adalah publikasi dijurnal ilmiah, publikasi artikel dimedia massa, dokumentasi kegiatan dalam bentuk video yang diupload di youtube, partisipasi pembicara berskala nasional, jumlah masyarakat yang tertarik dan mengikuti kegiatan, dan angka partisipasi dosen dan mahasiswa. 


\section{Hasil dan Pembahasan}

\subsection{Sosialisasi mengenai Pandemik Covid-19}

Kegiatan ini terintegrasi dengan mata kuliah (wajib) Perencanaan Infrastruktur Wilayah dan Kota (3 SKS) yang disajikan pada semester 3 yang saat itu diambil oleh mahasiswa angkatan 2017 dan dibimbing secara intensif oleh tiga dosen pengampunya. Tujuan diadakannya kegiatan ini adalah agar masyarakat memperoleh, diantaranya yaitu: 1) pemahaman mengenai cara penularan virus SARS-CoV2 penyebab penyakit Covid-19, 2) pemahaman mengenai cara proteksi diri dan keluarga melalui ide, pola dan kebiasaan baru yang lebih sehat dan langkah pengobatannya jika tertular; 3) semangat dan optimisme dalam menghadapi Covid-19; 4) pelajaran mengenai sikap terbaik dalam mematuhi kebijakan penanganan yang dilakukan oleh Pemerintah pusat dan daerah; dan 5) motivasi/dorongan untuk ikut berperan dan berkontribusi sesuai kapasitasnya masing-masing.

Tujuan diadakannya kegiatan ini bagi mahasiswa, diantaranya, yaitu: 1) Mendorong mahasiswa untuk mencari tahu secara mandiri mengenai pandemik Covid-19 yang sementara mereka alami; dan 2) Membuka ruang diskusi kelompok dan kelas (dibimbing oleh dosen pengampu) dalam upaya memahami lebih lanjut mengenai kebijakan dan dampak penanganan Covid-19 yang dilakukan oleh pemerintah dan negara-negara lain di dunia, termasuk Physical Distancing, Distance Learning dan Work from Home (WFM) yang mahasiswa baru saja jalani saat itu dan kedua poin ini sedikit banyak membantu meredakan kebingungan dan stress yang mereka alami.

Selain dari dua poin tersebut, kegiatan ini juga bertujuan: 3) Melatih kepekaan dan kepedulian sosial mahasiswa sejak dini terhadap kondisi sulit akibat pandemik yang dihadapi oleh masyarakat dan Pemerintah; 4) Menanamkan nilai-nilai dan kepercayaan bahwa mereka memiliki peran, tugas dan tanggungjawab untuk berkontribusi membantu masyarakat dan pemerintah menghadapi kondisi tersebut; 5) Mengembangkan gagasan, kreatifitas dan kapasitas mereka untuk menghasilkan gagasan/solusi sesuai bidang keilmuannya; 6) Mengembangkan kemampuan mengkomunikasikan gagasan/solusi tersebut secara efektif kedalam bahasa, format dan media yang mudah untuk dipahami dan diakses oleh masyarakat dari segala kalangan; 7) Mengembangkan kemampuan mereka untuk hidup bermasyarakat dan berinteraksi sosial dengan dunia luar; 8) memperluas jaringan pergaulan mereka dan menjadi teladan agen perubahan/pergerakan, utamanya bagi anak muda lainnya; dan 9) Menanamkan hikmah yang dengannya membentuk pemahaman, pengalaman, dan kesiapan mereka sebagai calon-calon pemimpin untuk menghadapi pandemik dan bencana-bencana lainnya dimasa depan. Gambar 1 memperlihatkan bagaimana setiap kelompok mengkomunikasikan alur pikir dan konten pada karya yang mereka bikin dihadapan teman-temannya dan dosen pengampu mata kuliah secara daring.


Gambar 1. Mahasiswa menjelaskan karya yang dibuatnya via zoom 
Berikut tema-tema (pada tabel 1, 2, dan 3) dan contoh bahan materi sosialisasi (pada gambar 2, 3, dan 4) yang diunduh mahasiswa ke Instagram dan Youtube.

Tabel 1. Tema sosialisasi Covid-19 melalui format foto

\begin{tabular}{|c|c|l|}
\hline No & Foto & \multicolumn{1}{c|}{ Judul, Tanggal unduh dan Halaman Website } \\
\hline 1 & Satir & $\begin{array}{l}\text { Simalakama COVID-19 (Instagram, 24 April 2020) } \\
\text { https://www.instagram.com/p/B_W8QgbnnvTMaSxFIVQyNIFQ2cAOi9YdKrzGjU0/?igshid=ouqqmx9m } \\
\text { npfl }\end{array}$ \\
\hline 2 & Satir & $\begin{array}{l}\text { Setiap Masa Punya Pelaku (Instagram, 24 April 2020) } \\
\text { https://www.instagram.com/p/B_XHzgdFxNp/?igshid=syrxa3addchn }\end{array}$ \\
\hline 3 & Satir & $\begin{array}{l}\text { 2 Takdir “Fear and Dangerous" (Instagram, 20 April 2020) } \\
\text { https://www.instagram.com/p/CAuWnJAFWCehzlUMGkdn3KzHTRNmw_tbe- } \\
\text { DiXc0/?igshid=5wvf4fi5y4qt }\end{array}$ \\
\hline 4 & Inspiratif & $\begin{array}{l}\text { Mengistirahatkan Keramaian (Instagram,21 April 2020) } \\
\text { https://www.instagram.com/p/B_PBiv4FFgyn8R15RKutZp-s-yrf8BDR2UdIVI0/?igshid=3vye1j98dh25 }\end{array}$ \\
\hline 5 & Inspiratif & $\begin{array}{l}\text { Stay Home, Stay Safe } \text { (Instagram,22 April 2020) } \\
\text { https://www.instagram.com/p/B_RBGGXBL9b/?igshid=1feg8njuow8ol }\end{array}$ \\
\hline 7 & Inspiratif & $\begin{array}{l}\text { Siapakah Kita di Tengah Wabah Covid-19 Ini? (Instagram, 7 April 2020) } \\
\text { https://www.instagram.com/p/B-dMhdGHkgk/?igshid=105qewhg3sufc }\end{array}$ \\
\hline Inspiratif & $\begin{array}{l}\text { Cara Pencegahan Covid-19 (Instagram, 13 April 2020) } \\
\text { https://www.instagram.com/p/B-6mr4wlhA2YQvqlCmcuaVBd- } \\
\text { 007YCH1h_4Vdk0/?igshid=666dgv04wzzy }\end{array}$ \\
\hline
\end{tabular}
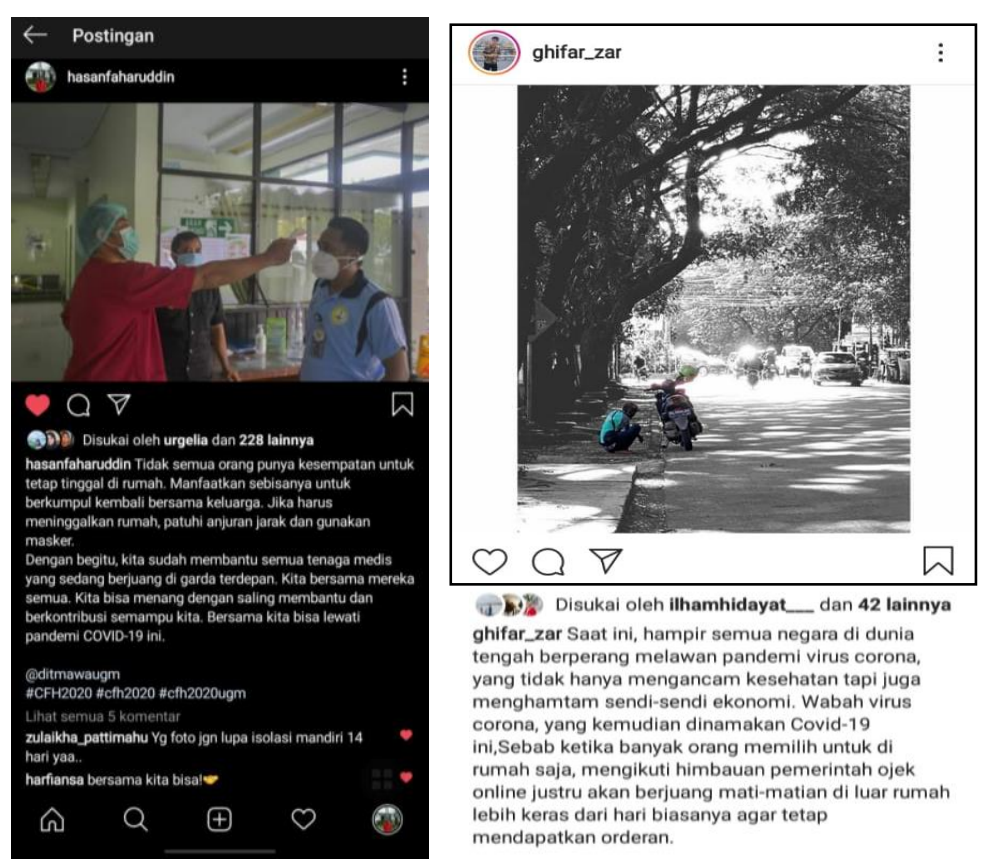

(4) Disukai oleh ilhamhidayat__ dan 42 lainnya ghifar_zar Saat ini, hampir semua negara di dunia tengah berperang melawan pandemi virus corona, yang tidak hanya mengancam kesehatan tapi juga menghamtam sendi-sendi ekonomi. Wabah virus corona, yang kemudian dinamakan Covid-19 ini,Sebab ketika banyak orang memilh untuk di rumah saja, manghuthimbauan pemerintah ojek online justru akan berjuang mati-matian di luar rumah lebih keras dari hari biasanya agar teta mendapatkan orderan

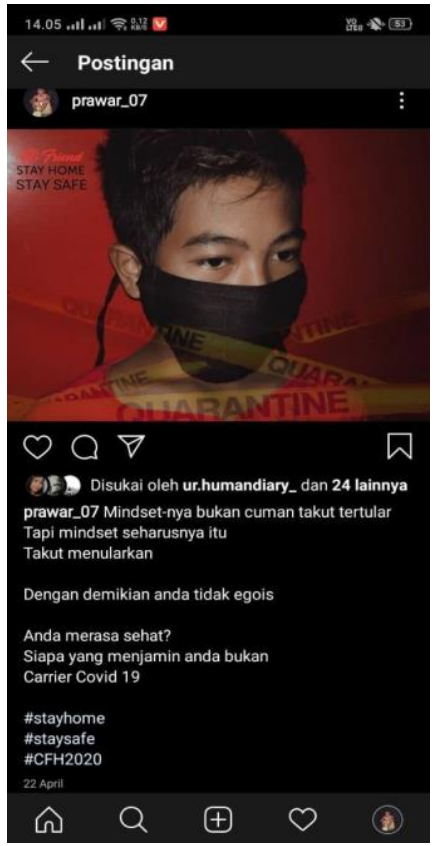

Gambar 2. Sosialisasi informasi mengenai Covid-19 melalui format foto

Tabel 2. Tema sosialisasi Covid-19 melalui format poster

\begin{tabular}{|c|c|l|}
\hline No & Poster & \multicolumn{1}{c|}{ Judul, Tanggal unduh dan Halaman Website } \\
\hline 1 & Edukatif & $\begin{array}{l}\text { 5 Cara Menerapkan Physical Distancing (Instagram, 24 April 2020) } \\
\text { https://www.instagram.com/p/B_WzWIzH7yU/?igshid=1670h5dy6s7gk }\end{array}$ \\
\hline 2 & Edukatif & $\begin{array}{l}\text { Physical Distancing (Instagram,22 April 2020) } \\
\text { https://www.instagram.com/p/B_RjTpvlS2P/ }\end{array}$ \\
\hline 3 & Edukatif & Physical Distancing (Posted Instagram,25 April 2020) \\
\hline
\end{tabular}




\begin{tabular}{|c|c|l|}
\hline & & https://www.instagram.com/p/B_VCkxBlqQ1/?igshid=spqf0f2fcenj \\
\hline 4 & Edukatif & $\begin{array}{l}\text { Melewati Masa Physical Distancing di Rumah Dengan Cara Asik (Instagram, 25 April 2020) } \\
\text { https://www.instagram.com/p/B_ZQXTuh4wa/?igshid=rjxikiqiyn0x }\end{array}$ \\
\hline 5 & Edukatif & $\begin{array}{l}\text { Ayo Lawan COVID-19 (Instagram, 24 April 2020) } \\
\text { https://www.instagram.com/p/CAuO48PFI1nwEflov0rdkMhdgWioIkd6kuRD7c0/?igshid=117ei6spfr1ym }\end{array}$ \\
\hline 6 & Edukatif & $\begin{array}{l}\text { It's not Social Distancing } \text { but Physical Distancing (Instagram, 23 April 2020) } \\
\text { https://www.instagram.com/p/B_U5e9nJiiq/?utm_source=ig_web_copy_link }\end{array}$ \\
\hline 7 & Edukatif & $\begin{array}{l}\text { Physical Distancing (Instagram, 21 April 2020) } \\
\text { https://www.instagram.com/p/B_NeucSAv7E/?igshid=1a8pxfsdg3djf }\end{array}$ \\
\hline 8 & Edukatif & $\begin{array}{l}\text { Pahami Penyebaran Covid-19 Pakai Masker dengan Cermat (Instagram, 12 Mei 2020) } \\
\text { https://www.instagram.com/p/CAFJTtP153t/?igshid=1waltafidf1lz }\end{array}$ \\
\hline 9 & Edukatif & $\begin{array}{l}\text { Karantina Wilayah dan Strategi Menjamin Logistik dan Kebutuhan Masyarakat (Instagram 24 April } \\
\text { 2020): https://www.instagram.com/p/B_WbM21j4kJ/?igshid=1u935tazoxo88 }\end{array}$ \\
\hline
\end{tabular}

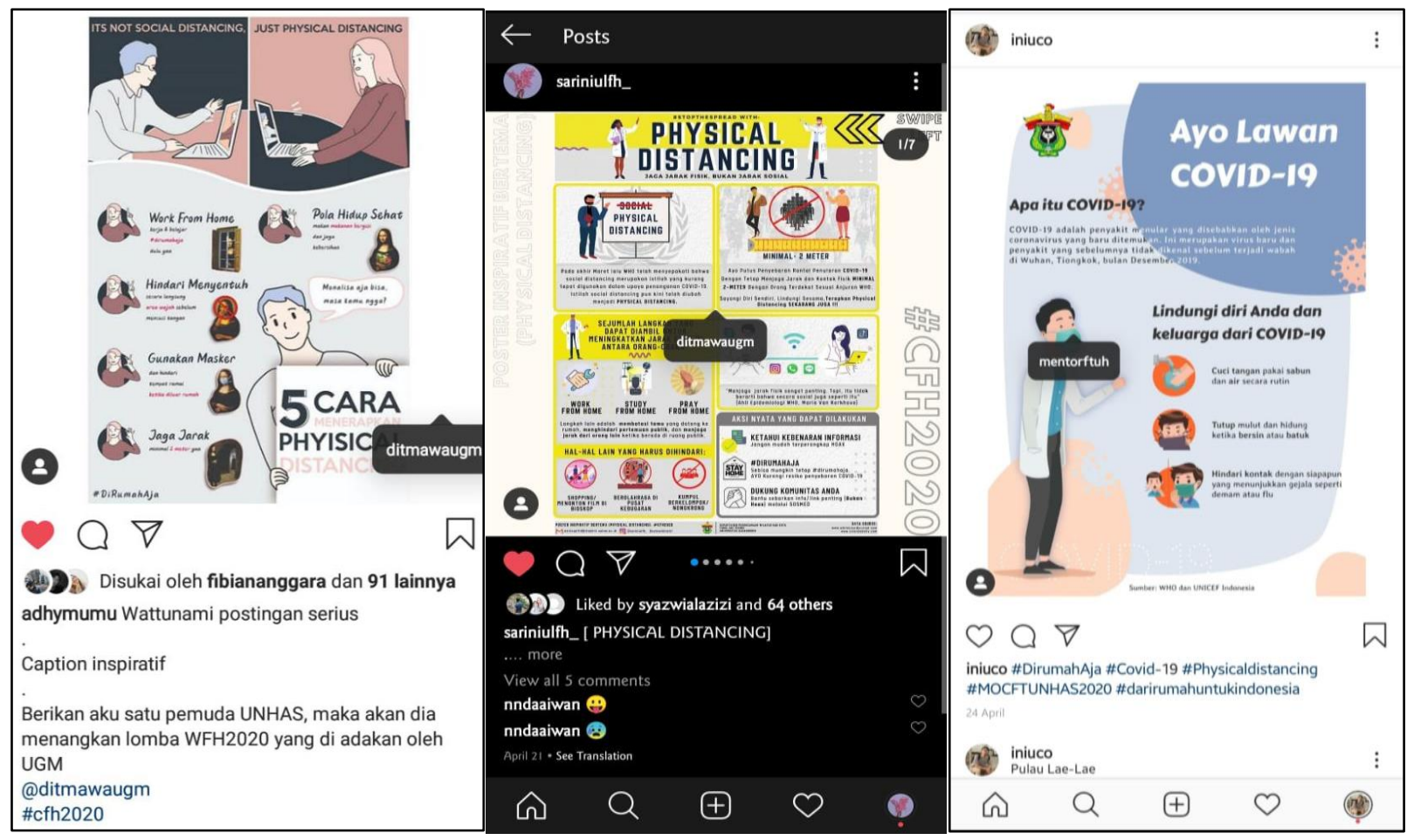

Gambar 3. Sosialisasi informasi mengenai Covid-19 melalui format poster

Tabel 3. Tema sosialisasi Covid-19 melalui format video

\begin{tabular}{|c|c|l|}
\hline No & Video & \multicolumn{1}{c|}{ Judul, Tanggal unduh dan Halaman Website } \\
\hline 1 & Animatif & $\begin{array}{l}\text { Apakah corona itu? (Instagram,25 April 2020) } \\
\text { https://www.instagram.com/p/B_Z7amilU8s/?igshid=2ywwecmv8f0o }\end{array}$ \\
\hline 2 & Animatif & $\begin{array}{l}\text { Pencegahan COVID-19 (Instagram, 25 April 2020) } \\
\text { https://www.instagram.com/tv/CAuWwL0AJoO/?igshid=1q4btwfqqcg8v }\end{array}$ \\
\hline 3 & Animatif & $\begin{array}{l}\text { Hal Apa Saja yang Bisa Dilakukan Saat Covid-19 (Youtube, 20 April 2020) } \\
\text { https://youtu.be/crZnBrKbxZs }\end{array}$ \\
\hline 4 & Animatif & $\begin{array}{l}\text { Pencegahan Penyebaran Covid-19 (Youtube, 25 April 2020) } \\
\text { https://youtu.be/cHv_ghpGKoo }\end{array}$ \\
\hline 5 & Animatif & $\begin{array}{l}\text { Tips Pencegahan Penularan Covid-19 (Youtube, 22 April 2020) } \\
\text { https://www.youtube.com/watch?v=mmcZV53cCKk\&feature=youtu.be }\end{array}$ \\
\hline 6 & Animatif & $\begin{array}{l}\text { Penularan Covid (Instagram,21 April 2020) } \\
\text { https://www.instagram.com/p/B_OiyRol2i3XnFybOMxVMXXdoOokv9EIm20KII0/?igshid=11cfosu24dc } \\
\text { qk }\end{array}$ \\
\hline
\end{tabular}




\begin{tabular}{|c|c|l|}
\hline 7 & Edukatif & $\begin{array}{l}\text { 5 Cara Mudah Menjaga Diri Dari Virus Corona (Instagram, 21 April 2020) } \\
\text { https://www.instagram.com/p/CAuXuvSnIkOPtD0qt67iMOT8S7h225ILLN4bk00/?igshid=1cah0rhfvp9p7 }\end{array}$ \\
\hline 8 & Edukatif & $\begin{array}{l}\text { Fakta dan Mitos terkait Virus Covid-19 (Instagram, 3 Mei 2020) } \\
\text { www.instagram.com/p/CAuXGmaAL2ZgGP82M1os2a9ztlRK7eeZ92IZEo0/?hl=id }\end{array}$ \\
\hline 9 & Edukatif & $\begin{array}{l}\text { Covid-19 dan Cara Mengatasinya (Youtube, 25 April 2020) } \\
\text { http://www.youtube.com/watch?v=R8nMShG6AU }\end{array}$ \\
\hline 10 & Edukatif & $\begin{array}{l}\text { Physical Distancing (Youtube,21 April 2020) } \\
\text { https://youtu.be/paie9oplJNU }\end{array}$ \\
\hline 11 & Edukatif & $\begin{array}{l}\text { Produktif \#DiRumahAja (Youtube,26 April 2020) } \\
\text { htps://www.instagram.com/p/B_aTmDDg9HOT00hYaVOQgw7fKUArSBX4OlEO6c0/?igshid=1e5rjxeu } \\
\text { xyqvs }\end{array}$ \\
\hline 12 & Edukatif & $\begin{array}{l}\text { Tetap Dirumah Aja (Youtube,22 April 2020) } \\
\text { https://youtu.be/NSZ9PIMPD1k }\end{array}$ \\
\hline 13 & Presentasi & $\begin{array}{l}\text { Strategi Penanganan Covid-19 di Eropa (Instagram, 24 April 2020) } \\
\text { https://www.instagram.com/p/B_XnYFgl14mF_KiELcNvCwqPXJSJ6tS_7WnhfY0/?igshid=17ohpny61cs } \\
\text { re }\end{array}$ \\
\hline 14 & Presentasi & $\begin{array}{l}\text { Strategi Penanganan Covid-19 di Indonesia, Belajar dari China, Malaysia, Singapura, dan Saudi } \\
\text { Arabia (Instagram, 18 April 2020) } \\
\text { https://www.instagram.com/p/CAuQpSpHNoH/?igshid=76qgqq9tx7dh }\end{array}$ \\
\hline 15 & Presentasi & $\begin{array}{l}\text { Strategi Penanganan Covid-19 di Indonesia (Instagram, 7 April 2020) } \\
\text { https://www.instagram.com/dewisrist_/?hl=id }\end{array}$ \\
\hline 16 & Presentasi & $\begin{array}{l}\text { Asosiasi Logistik dalam Menyusun Regulasi terkait Karantina } \\
\text { Wilayah sebagai Salah Satu Upaya untuk Mencegah Penularan Covid 19 (Instagram, 28 Mei 2020): } \\
\text { https://www.youtube.com/watch?v=LcaMlD5K1qQ\&feature=youtu.be }\end{array}$ \\
\hline
\end{tabular}
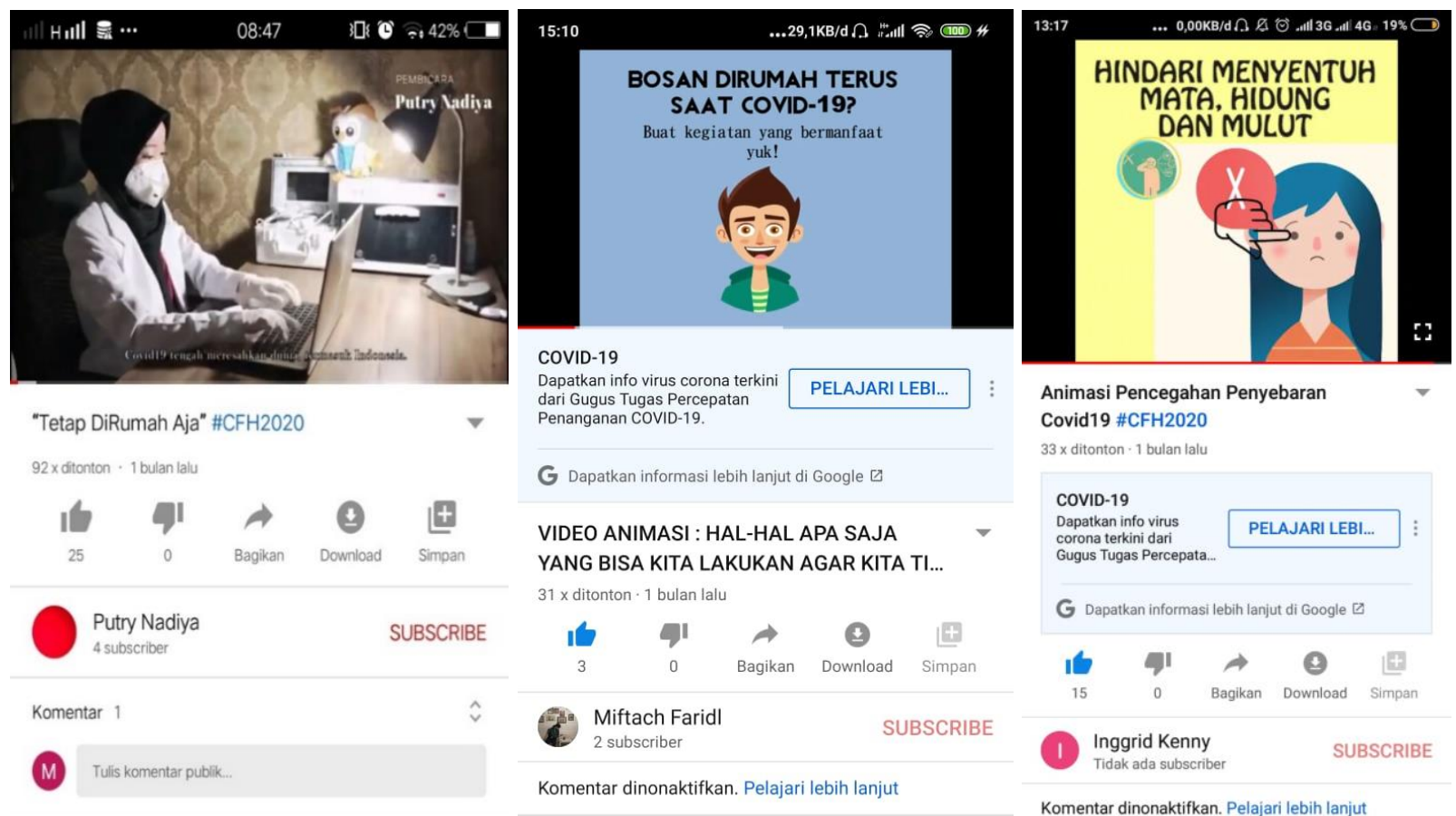

Gambar 4. Sosialisasi informasi mengenai Covid-19 melalui format video

Total sebanyak 32 foto, poster dan video yang diunduh kesitus instagram dan youtube pada April dan Mei 2020 dan sampai dengan hari ini (10 Oktober) telah tercapai 4,037 peninjauan (viewers). Jumlah viewers ini telah melebihi dari target 1,000 viewers yang diharapkan diawal kegiatan. 
Tabel 4. Total foto, poster dan video sosialisasi informasi mengenai Covid-19

\begin{tabular}{|l|c|c|c|c|}
\hline Sosialisasi & Foto & Poster & Video & Total \\
\hline Jumlah & 7 & 9 & 16 & 32 \\
\hline Media & Instagram & Instagram \& Youtube & Instagram & - \\
\hline Comments & 15 & 97 & 97 & 209 \\
\hline Likes & 622 & 1,030 & 378 & 2,030 \\
\hline Viewers & 622 & 3,037 & 378 & 4,037 \\
\hline
\end{tabular}

Adapun tantangan dan kendala yang dihadapi dalam kegiatan ini, diantaranya yaitu: 1) sebagian besar mahasiswa belum pernah melakukan sosialisasi melalui format foto, poster dan video sehingga membuat karyanya belum optimal; 2) sebagian besar juga belum pernah menayangkan (posting) karyanya melalui media massa (youtube dan instagram) sehingga perlu dorongan/motivasi lebih lanjut dari dosen pengampu; 3) karena belum terbiasa dengan distance learning dan terkendala sinyal telekomunikasi yang terkadang tidak stabil sehingga sebagian besar kelompok kurang optimal dalam berkoordinasi dan bekerjasama; 4) rasa malu dan tidak percaya diri membuat sebagian kelompok menonaktifkan kolom komentar pada karya yang diunduh; dan 5) kemungkinan karena hal ini juga sehingga beberapa karya tidak bisa lagi diakses saat ini karena telah diturunkan dari media sesaat setelah perkuliahan semester berakhir.

\subsection{Seminar Nasional Virtual Konsep Kota Cerdas, Sehat, Tangguh Pandemik}

Tujuan dan sasaran diadakannya kegiatan ini, diantaranya yaitu: 1) Untuk mendiseminasikan/menyebarluaskan ide, gagasan dan inovasi konsep kota yang tangguh pandemik; 2) Sebagai sumbangsih nyata keilmuan, keahlian, dan pengalaman kepada pemerintah dan masyarakat luas; 3) Mendorong pemikiran, penelitian, perencanaan serta realisasi konsep ini sesegera mungkin sebagai upaya antisipasi terjadinya pandemik dimasa depan; 4) Mewadahi pertemuan dan ruang diskusi kepada khalayak ramai utamanya para pelaku dunia perencanaan yang berasal dari beragam kota dan kabupaten; dan 5) membuka dan menjembatani langkah kolaborasi dan kerjasama antara pihak-pihak terkait dimasa depan. Untuk mendukung tujuan ini, Departemen PWK mengundang secara resmi pimpinan dan staf dari 12 kantor dinas pemerintahan Kota Makassar (KM) dan Provinsi Sulsel (PS) yang berkaitan dengan bidang perencanaan wilayah dan kota (gambar 5). Dinas-dinas ini diantaranya: 1) Penataan Ruang KM; 2) Pekerjaan Umum KM; 3) Perumahan dan Kawasan Permukiman KM; 4) Lingkungan Hidup KM; 5) Pengelolaan Lingkungan Hidup PS; 6) Perhubungan KM; 7) Perhubungan PS; 8) Sumber Daya Alam, Cipta Karya, dan Tata Ruang PS; 9) Pembangunan Daerah KM; 10) Pariwisata KM; 11) Badan Penanggulangan Bencana Daerah KM; dan 12) Pertanahan KM.


Gambar 5. Undangan secara resmi ke dinas-dinas terkait di Kota Makassar 
Kegiatan ini diselenggarakan oleh tim dosen PWK Unhas dan menghadirkan 5 pembicara yang ahli dibidangnya (gambar 6). Pembicara pertama yaitu ketua Satgas Covid-19 Unhas (Prof. dr. Budu, ph.D., Sp. M(K)., M.Med. Ed.) yang membahas mengenai prinsip dasar ketahanan medis kota tangguh pandemik. Pembicara kedua yaitu ahli transportasi dari PWK Unhas (Prof. Dr.-Ing. Ir. Muhammad Yamin Jinca, M.Str.) yang membahas mengenai ketahanan infrastruktur dan logistik kota tangguh pandemik. Pembicara ketiga yaitu ahli perencanaan kota dari PWK Unhas (Prof. Dr. Ir. Ananto Yudono, M.Eng.) yang membahas tentang ide konsep kota cerdas, sehat dan tangguh pandemik. Pembicara keempat yaitu ketua Asosiasi Sekolah Perencanaan Indonesia (Dr. Iwan Rudiarto, M.Sc.) yang membahas mengenai kurikulum pendidikan perencanaan yang cerdas dan adaptif yang diperlukan untuk menyiapkan calon-calon perencananya. Pembicara kelima yaitu ketua Ikatan Ahli Perencana Pusat (Dr.Phil. Hendricus Andy Simarmarta, ST., M.Si.) yang membahas mengenai kompetensi dan profesionalisme dalam implementasinya.

Kegiatan ini dilaksanakan pada tanggal 24 September secara virtual. Kata sambutan disampaikan oleh Dekan Fakultas Teknik Unhas dan pembukaan dilakukan oleh Wakil Rektor Unhas bidang perencanaan keuangan dan infrastruktur yang juga merupakan ahli dibidang perencanaan wilayah dan kota, mewakili Rektor Unhas,
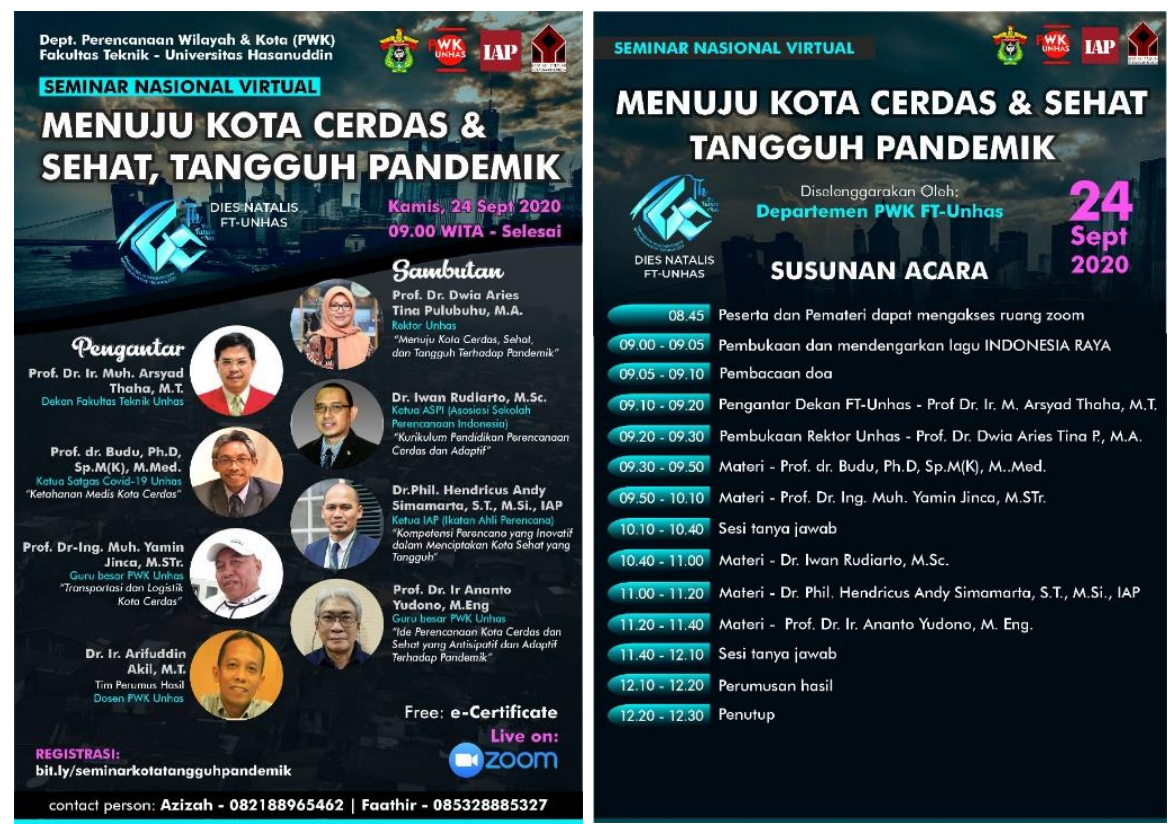

Gambar 6. Liflet dan jadwal seminar

Calon peserta yang mendaftar sejak 7 hingga 1 hari sebelum acara mencapai 1,008 orang dengan komposisi: 86 orang dari 31 dinas pemerintahan dan kementerian, 284 peserta dari 82 universitas di luar Sulsel, 100 peserta dari 20 universitas di dalam Sulsel, 3 peserta dari IAI (Ikatan Arsitek Indonesia), dan 18 peserta dari IAP (Ikatan Ahli Perencana Indonesia). Jumlah peserta yang hadir pada saat acara dilaksanakan dan mengisi lembar kehadiran yang diedarkan sekitar 60 menit sebelum acara berakhir mencapai 584 orang dengan komposisi: 42 orang berasal dari 22 dinas emerintahan dan kementerian, 135 orang dari 46 universitas di luar Sulsel, 10 orang dari 7 
wilayah IAP, dan 10 orang dari 6 konsultan/institut perencanaan/arsitektur (gambar 7). Jumlah partisipasi ini telah melebihi dari target 300 peserta yang ditetapkan diawal kegiatan.

\begin{tabular}{|l|}
\hline Universitas di dalam Sulawesi Selatan \\
Politeknik Ilmu Pelayaran Makassar \\
Politeknik Negeri Ujung Pandang \\
Politeknik Pertanian Negeri Pangkep \\
Sekolah Tinggi KP Balikdiwa Makassar \\
Universitas Islam Negeri Alauddin Makassar \\
Universitas Bosowa \\
Universitas Muhammadiyah Bulukumba \\
Universitas Muhammadiyah Makassar \\
Universitas Muhammadiyah Sinjai \\
Universitas Negeri Makassar \\
Universitas Terbuka \\
\hline \hline Kementerian dan Dinas Pemerintahan \\
Kementerian Pekerjaan Umum dan Penataan Ruang \\
Kementerian Agraria dan Tata Ruang \\
Kementerian Perhubungan \\
Kementerian Dalam Negeri \\
Kementerian Agama \\
Dinas Penataan Ruang \\
Dinas Pekerjaan Umum dan Penataan Ruang \\
Dinas Perumahan dan Permukiman \\
Dinas Perumahan Kaw. Permukiman \& Pertanahan \\
Dinas Lingkungan Hidup dan Kehutanan \\
Dinas Pendidikan \\
Dinas Kehutanan \\
Dinas Komunikasi dan Informatika \\
Badan Perencanaan, Penelitian dan Pengembangan \\
Badan Perencanaan dan Pembangunan Daerah \\
Badan Penanggulangan Bencana Daerah \\
Badan Pengelola Keuangan Haji \\
Pemerintah Kota Kendari \\
Kantor Wilayah Badan Pertanahan Nasional \\
Inspektorat Kabupaten Barru \\
Perusahaan Umum Daerah Air Minum \\
Kotaku - Dinas Pekerjaan Umum \\
\hline
\end{tabular}

\section{Organisasi Ikatan Ahli Perencana (IAP)}

Bali, DKI Jakarta, Sulbar, Sulsel, Sulut, Maluku Utara, dan Jawa Barat

\section{Konsultan Perencanaan/Arsitektur \\ Konsultan CV. AGP Konsultan Konsultan CV. Kiram Abadi Konsultan Konsultan CV. Karya Saoraja Konsultan Konsultan CV. Pangempa 19 Konsultan Rana Cipta Ma'rifat Institut Sulawesi Selatan}

\section{Universitas di luar Sulawesi Selatan}

Institut Manajemen Koperasi Indonesia

Institut Pertanian Bogor

Institut Teknologi Bandung

Institut Teknologi Kalimantan

Institut Teknologi Medan

Institut Teknologi Nasional Malang

Institut Teknologi Nasional Yogyakarta

Institut Teknologi Sumatera

IPDN Kampus Jatinangor

Sekolah Tinggi Arsitektur YKPN Yogyakarta

Sekolah Tinggi Ilmu Komputer Ambon

UIN Syarif Hidayatullah Jakarta

Universitas Airlangga

Universitas Amikom Yogyakarta

Universitas Brawijaya

Universitas Gadjah Mada

Universitas Halu Oleo

Universitas Indraprasta PGRI Jakarta

Universitas Islam Bandung

Universitas Kristen Indonesia Maluku

Universitas Lambung Mangkurat

Universitas Lampung

Universitas Mahasaraswati Denpasar

Universitas Mercu Buana Jakarta

Universitas Muhammadiyah Banjarmasin

Universitas Muhammadiyah Gorontalo

Universitas Muhammadiyah Malang

Universitas Musamus

Universitas Negeri Gorontalo

Universitas Negeri Surabaya

Universitas Nusa Cendana Kupang

Universitas Nusantara Manado

Universitas Pakuan

Universitas Panca Bhakti

Universitas Pasundan

Universitas Pattimura Ambon

Universitas Pelita Harapan

Universitas Podomoro

Universitas Sam Ratulangi

Universitas Sriwijaya

Universitas Sulawesi Barat

Universitas Syiah Kuala

Universitas Tadulako

Universitas Tanjungpura

Universitas Teknologi Yogyakarta

Universitas Udayana

Gambar 7. Asal instansi peserta seminar nasional virtual Dep. PWK Unhas 
Suasana jalannya seminar dapat dilihat pada gambar 8 dibawah ini.
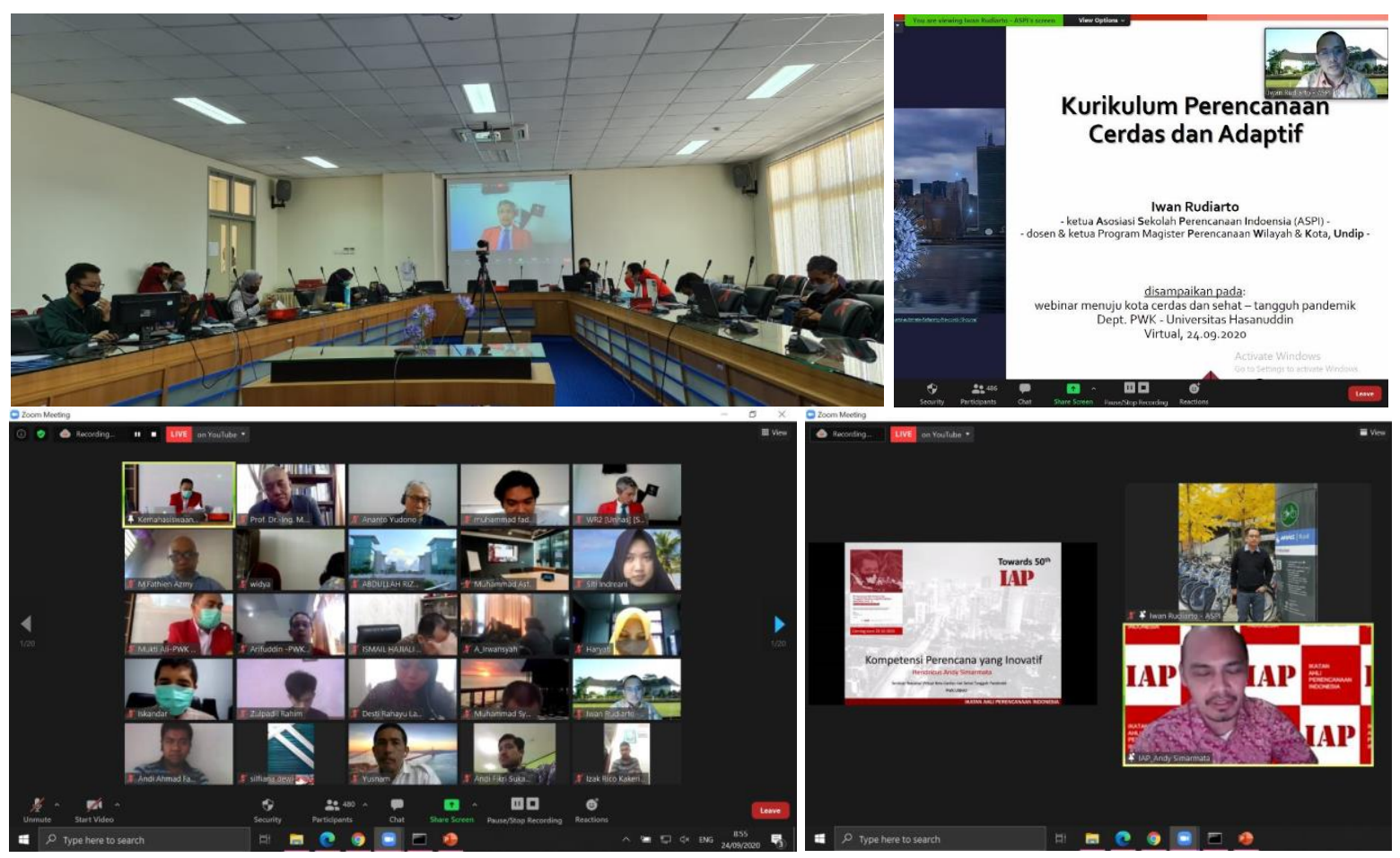

Gambar 8. Jalannya seminar nasional virtual PWK Unhas, 24 September 2020

Berikut rangkuman beberapa materi yang dibawakan oleh pembicara dalam seminar tersebut. Strategi utama dalam ketahanan medis, diantaranya yaitu:

1) Perencanaan pembatasan akses masuk/keluar kota (lockdown) secara menyeluruh/sebagian;

2) Penerapan kebijakan test-trace-treat secara massal dan agresif;

3) Penyediaan laboratorium diagnosa dengan kuantitas dan kualitas yang baik untuk memudahkan test-trace secara massal disepanjang proses pengendalian virus, utamanya pada tahap awal;

4) Penyediaan rumah sakit rujukan sebagai pusat utama perawatan dengan jumlah dan kualitas yang memadai;

5) Penyediaan rumah sakit penyangga yang meski memiliki kapasitas dan kualitas dibawah rumah sakit rujukan namun berperan sangat penting dalam penanganan awal pasien sebelum terkonfirmasi positif melalui hasil test laboratorium dan dirujuk ke rumah sakit rujukan;

6) Penyediaan pusat-pusat karantina lokal yang mampu menampung massa yang besar;

7) Kemungkinan pengalihfungsian hotel dan penginapan yang tidak digunakan saat pandemik sebagai pusat-pusat karantina; dan

8) Pendataan tenaga kesehatan pendukung, untuk mengantisipasi kekurangan dokter spesialis dan pelayanan medis ke hotel/penginapan dan pusat karantina lokal lainnya.

Strategi utama dalam ketahanan Infrastruktur transportasi dan logistic, yaitu: 
1) Pelayanan transportasi umum wajib mendukung diberlakukannya peraturan menjaga jarak (physical distancing) di masa pandemik Covid-19, misalnya dengan merenggangkan jarak kursi di dalam kendaraan, di ruang tunggu, dan jarak antrian di loket tiket;

2) Perlunya antisipasi berkurangnya tingkat penggunaan kendaraan umum (occupancy rate) saat pandemik terjadi yang berimbas pada meningkatnya biaya operasional transportasi;

3) Perlunya antisipasi perubahan pola interaksi antarmanusia yang sebelumnya face to face menjadi via perangkat digital, termasuk dalam sistem logistik;

4) Indeks ketahanan pangan di Pulau Sulawesi cukup baik (86.55\%) namun antisipasi perlu dilakukan pada wilayah Indonesia Timur seperti Maluku dan Papua yang memiliki indeks sangat rendah. Disamping itu, hampir seluruh pulau di Indonesia masih memiliki ketergantungan yang tinggi terhadap komoditas Pulau Jawa dan hal ini rentan menyebabkan krisis logistik nasional manakala pelayanan transportasi logistik, utamanya laut, mengalami kemacetan, penundaan atau bahkan pemberhentian/disfungsional.

5) Kemenpan mengingatkan pentingnya meningkatkan indeks ketahanan pangan berbasis indikator ketersediaan bahan pangan, keterjangkauan dan kemanfaatan. Perhatian khusus perlu ditujukan ke daerah yang memiliki indeks yang masih rendah yaitu umumnya di Indonesia bagian timur. Konsumsi logistik Indonesia bagian timur tergolong negatif dan ini berdampak pada harga komoditas yang lebih tinggi dibandingkan harga rata-rata nasional dan berkontribusi terhadap ketimpangan pertumbuhan antarwilayah.

6) Tantangan bagi pengelola transportasi pada masa normal dan utamanya dimasa pandemik adalah menurunkan biaya logistik terutama di wilayah tertinggal, wilayah dengan tingkat ekonomi dan konsumsi logistic yang rendah.

7) Pentingnya mengantisipasi masalah yang berpotensi terjadi pada sistem transportasi dan logistik yang mengatur pergerakan komoditas dari daerah asal ke daerah tujuan, termasuk diantaranya faktor produsen, konsumer, regulasi, infrastruktur dan informasi.

8) Pentingnya menjadi keseimbangan permintaan (demand) dan penawaran (supply), salah satunya dengan menggunakan konsep brain system, blockchain dan robotic intelligence.

9) Pentingnya perhatian khusus terhadap 4 kebijakan utama pembentuk kota cerdas dan tangguh pandemik, yaitu kestabilan ekonomi dan transportasi, adaptasi pola hidup sehat masyarakat dan penataan lingkungan fisik/ruang hidup bersama (common living space).

10) Pentingnya memperhatikan sumber-sumber konsumsi masyarakat baik yang berbasis produk lokal yang didatangkan dari lahan-lahan produksi pertanian setempat maupun yang berbasis produk luar negeri (import) melalui bandara dan pelabuhan.

11) Pentingnya aplikasi CIT (Communication Information and Technology) dan CIM-CIT (Computer Integrated Manufacturing/Computer Integrated Transportation) untuk mengefektifkan distribusi pangan.

12) Target pencapaian kota cerdas adalah mencerdaskan kehidupan bangsa untuk mencapai kesejahteraan, keadilan dan perdamaian (Amanah UUD 45). Hal ini dapat dicapai melalui pendayagunaan CIT dan CIM-CIT sebagai peralihan dari pola komunikasi F2F/C2C/C2M/M2M (Face to Face/Customer to Customer/Customer to Manufacture, Manufacture to Manufacture) sebagai upaya cerdas meningkatkan kemudahan pelayanan publik sehingga memberikan keuntungan ekonomi, sosial, dan lingkungan serta berdaya guna untuk meningkatkan kualitas hidup masyarakat;

13) Logistik kota cerdas berbasis QCDS (Quality, Control, Delivery and Service) dengan target peningkatan efisiensi dan efektifitas pada jaringan dan simpul-simpul transportasi; 
14) Kota yang cerdas dibentuk oleh sistem transportasi yang cerdas (smart transportation system) yang bertumpu pada 4 kebijakan utama yaitu RTRW Nasional/Provinsi/ Kabupaten/Kota, SisTraNas (Sistem Transportasi Nasional), SisLogNas (Sistem Logistik Nasional), dan CIT-IoT (Communication Information and Technology - Internet of Things);

15) Untuk mengoptimalkan potensi SDA (Sumber Daya Alam), pusat-pusat produksi, dan pertumbuhan ekonomi, serta mengatasi pembangunan infrastruktur wilayah yang tidak merata, diperlukan integrasi kebijakan RTRWN/P/K, SisLogNas, SisTraNas, dan CIT-IoT sehingga menjamin penyediaan informasi secara akurat dan real time (terkini) mengenai lokasi/letak, kualitas, kuantitas, dan fluktuasi produksi, dan mendukung kestabilan ketersediaan, keterjangkaan dan pemanfaatan komiditas pangan masyarakat;

Kurikulum Perencanaan yang Cerdas dan Adaptif

1) Tantangan kurikulum pendidikan saat ini adalah membentuk kompetensi lulusan untuk perencanaan kota yang cerdas dan adaptif serta responsif terhadap isu-isu strategis baik yang sifatnya global maupun lokal, ekternal maupun internal, seperti peningkatan populasi, tuntutan pelayanan fasilitas dan infrastruktur yang lebih baik, globalisasi, sistem global mega-trends-ICT, literasi industri 4.0, dan bencana seperti pandemic Covid-19.

2) Setiap perencana memiliki kapasitas untuk mendefinisikan, menganalisis dan mendebat isuisu tentang konsep smart city karena ini adalah strategi berbasis permasalahan dan kemampuan setempat (place-based strategy). Smart city merujuk pada penggunaan informasi dan teknologi untuk menggalang partisipasi dan melayani kebutuhan masyarakat serta meningkatkan sistem perkotaan. Penggunaan teknologi ini akan menghasilkan efisiensi dalam pembiayaan, ketangguhan sistem infrastruktur dan peningkatan urban experience. Smart adaptive contohnya adalah urban analytics yang mengaplikasikan metode quantitative, computational, design dan visual methods pada struktur spasial dan morfologi kota dan wilayah. Konsep ini juga terkait dengan big data.

3) Desain pembelajaran masa kini memanfaatkan teknologi IT dan metode blended learning.

4) Kompetensi PWK yang diharapkan dalam mata kuliah baru terkait industri 4.0 tersebut sebaiknya mencakup pengetahuan dan keterampilan khusus dengan rumusan CPL terdiri dari: (a) literasi data yaitu kemampuan pemahaman untuk membaca, menganalisis, menggunakan data dan informasi (big data) didunia digital; (b) literasi teknologi yaitu kemampuan memahami cara kerja mesin, aplikasi teknologi (coding, artificial intelligence,d an engineering principle); (c) literasi manusia yaitu kemampuan dan pemahaman tentang humanities, komunikasi dan desain; (d) literasi industri 4.0; dan (e) literasi ilmu diamalkan bagi kemaslahatan bersama secara lokal, nasional dan global.

5) Kurikulum outcome-based education menuntut penguasaan ilmu yang harus sejalan dengan kebutuhan sosial, industri/bisnis, dan profesi.

6) Program studi (prodi) perlu melakukan evaluasi kurikulum per lima tahun dan per tahun. Evaluasi tahunan diperlukan untuk memperkaya misalnya pengadaan mata kuliah baru (seperti mata kuliah IoT di Undip) atau perubahan nama mata kuliah. Evaluasi per 5 tahun diperlukan untuk pengembangan kurikulum yang lebih jauh dengan mempertimbangkan kekuatan (seperti jumlah staf, kapasitas sarana), kelemahan (seperti budaya akademis, manajemen, dan kualitas input), peluang (seperti potensi kolaborasi dan dana penelitian kompetitif) dan tantangan (seperti teknologi IT, gagasan baru dan tuntutan pasar).

7) ASPI telah menyepakati bahwa kompetensi inti kurikulum pendidikan perencaaan harus mencakup mata kuliah planning process, planning studio, planning issues, planning theory, 
dan planning method. Diluar dari kompetensi inti ini dapat menjadi ciri khas ataupun pengayaan dalam konteks smart dan adaptive oleh prodi.

Ide dan gagasan dalam konsep kota cerdas, sehat dan tangguh pandemic, yaitu:

1) Pandemik Covid-19 menimbulkan dampak yang besar tetapi juga memberikan hikmah yang tidak kalah besar diantaranya yaitu mengingatkan kita untuk introspeksi diri, memperbaiki dan menjaga diri, pandai bersyukur dan memberi peluang untuk berinovasi;

2) Penataan kota yang antisipatif dan adaptif terhadap wabah penyakit sudah pernah dilakukan pada penyakit-penyakit seperti Japanese smallpox, Russian Flu, Spanish Flu, dan HIV/AIDS. Penataan kota berbasis wabah penyakit dikaitkan dengan konsep-konsep seperti arsitektur Barat, Timur, Nusantara, Garden City, dan Healthy City;

3) Kota tangguh pandemik direncanakan dan dirancang berdasarkan prinsip dasar penanganan pandemik Covid-19. Tantangan perencanaannya adalah bagaimana melakukan pencegahan penyebaran wabah penyakit seperti: isolasi (lockdown), pengontrolan keluar masuk orang dan/atau barang, peningkatan imunitas masyarakat dan menjaga produktif mereka meski terisolasi dirumah masing-masing.

4) Hal yang perlu diperhatikan dalam penataan ruang kota ini yaitu: (1) lockdown dengan sistem blok, dimana aksesibilitas, logistik dasar, dan kesiapan pintu kontrol telah diantisipasi dengan baik; (2) upaya penyehatan lingkungan misalnya bagaimana agar sinar matahari dapat masuk dengan bebas ke setiap rumah/bangunan, adanya sirkulasi udara yang baik diperkotaan, higenitas, dan tersedianya ruang terbuka publik serba guna; (3) penyediaan sarana dan prasarana konsultasi kesehatan, termasuk karantina dan perawatan pasien dengan memanfaatkan ICT; (4) penguatan sistem bekerja, sekolah, belanja, pertemuan secara daring; dan (5) desain dan peletakan lokasi hunian yang tepat bagi kaum rentan terpapar penyakit, (6) kota yang akomodatif bagi inovasi dunia usaha (UKM dan usaha besar) yang menggunakan sistem canggih; (7) Kota yang memiliki lembaga mitigasi yang tangguh dalam menanggulangi bencana penyakit menular.

5) Prinsip perencanaan kota cerdas oleh Barcelona pada tahun 2015 memberi pelajaran bagi kita bahwa: (1) perencanaan harus didasarkan pada jati diri kotanya; (2) prioritas pembangunan harus berbasis hasil analisis struktur sosial, ekonomi, budaya dan lingkungan kota; (3) arah pembangunan bersifat adaptif terhadap berbagai perubahan yang dinamis; (4) pelayanan ekonomi kota dilakukan bersama mitra/berbagai pihak; (5) jaminan investasi jangka panjang; (6) ketersediaan ruang publik bagi semua orang; (7) pembangunan kota yang terfokus pada aspirasi dan partisipasi masyarakat dengan memanfaatkan kemajuan teknologi; dan (8) desain kota yang mewujudkan transformasi dari sentralisasi ke desentralisasi yaitu kemandirian bagian-bagian wilayah kota.

6) Kota sehat, menurut WHO memiliki: (1) lingkungan yang sehat dan memenuhi kebutuhan dasar penduduknya; (2) kualitas kehidupan masyarakat yang baik; (3) pelayanan air bersih, dan sanitasi limbah yang efektif; dan (4) kemudahan akses ke pelayanan kesehatan.

Acara dan gagasan dalam seminar ini disebarluaskan melalui beragam media yaitu:

- Youtube Channel: https://www.youtube.com/watch?v=kfjKb7YrTzE

- PWK Unhas Website. 24 September 2020. Departemen Teknik Perencanaan Wilayah dan Kota, Fakultas Teknik, Universitas Hasanuddin, Melaksanakan Seminar Nasional Virtual dengan Tema: Menuju Kota Cerdas dan Sehat, Tangguh Pandemik. Web: https://eng.unhas.ac.id/pwk/id/news/44-departemen-teknik-perencanaan-wilayah-dan-kota,- 
fakultas-teknik,-universitas-hasanuddin-melaksanakan-seminar-nasional-virtual-dengan-temamenuju-kota-cerdas-dan-sehat,-tangguh-pandemik..html

- Unhas Website. 24 September 2020. FT Unhas Gelar Seminar Nasional Bahas Kota Cerdas, Sehat, dan Tangguh Pandemik. Web: https://unhas.ac.id/article/title/ft-unhas-gelar-seminarnasional-bahas-kota-cerdas-sehat-dan-tangguh-pandemik

- Antaranews Website. 25 September 2020. Akademisi Hadirkan Konsep Kota Sehat dan Tangguh Pandemik Covid-19. Web:

https://makassar.antaranews.com/amp/berita/213913/akademisi-hadirkan-konsep-kota-sehatdan-tangguh-pandemi-covid-19

- Matakita Website. 25 September 2020. FT Unhas Gelas Seminar Nasional Bahas Kota Cerdas Sehat dan Tangguh Pandemik. Web: https://matakita.co/2020/09/25/ft-unhas-gelar-seminarnasional-bahas-kota-cerdas-sehat-dan-tangguh-pandemik/

- Tribun Timur Website. 25 September 2020. FT Unhas Gelar Webinar, Bahas Kota Cerdas, Sehat dan Tangguh Pandemik. Web: https://makassar.tribunnews.com/amp/2020/09/25/ftunhas-gelar-webinar-bahas-kota-cerdas-sehat-dan-tangguh-pandemik

\section{Kesimpulan}

Departemen Perencanaan Wilayah dan Kota (PWK) Universitas Hasanuddin (Unhas) mendukung Pemerintah diantaranya melalui dua kegiatan pengabdian masyarakat sebagai bagian dari pelaksanaan tugas tridarma perguruan tinggi. Kegiatan pertama yaitu sosialisasi informasi mengenai Covid-19 kepada masyarakat melalui pendekatan edukatif, persuasif dan animatif dalam bentuk format tulisan, foto, poster dan video yang diunggah melalui youtube dan instagram pada April dan Mei 2020 dengan target $\pm 1,000$ peninjau (viewers). Kegiatan kedua yaitu diseminasi konsep Kota Cerdas, Sehat, dan Tangguh Pandemik sebagai upaya antisipasi terjadinya pandemik dimasa depan dengan pendekatan ilmiah, sistemis dan kolaboratif dalam bentuk format seminar nasional virtual yang diselenggarakan pada 24 September 2020 dengan target \pm 300 peserta. Kedua kegiatan ini telah dilakukan secara optimal dan telah mencapai target dan sasaran yang diharapkan.

\section{Ucapan Terima Kasih}

Penulis menghaturkan banyak terima kasih kepada pemimpin Fakultas Teknik dan Universitas Hasanuddin yang telah menghadiri dan sepenuhnya mendukung terlaksananya kegiatan ini baik secara moril dan administrasi, maupun finansial melalui dana hibah pengabdian masyarakat tahun 2020. Ucapan terimakasih juga dihaturkan kepada seluruh pemateri tamu, seluruh dosen, staf dan mahasiswa Departemen PWK Unhas yang telah berpartisipasi dan mendukung kelancaran seluruh kegiatan. 


\section{Daftar Pustaka}

Center for Disease Control and Prevention (CDC). 1918 Pandemic (H1N1 Virus). Website: https://www.cdc.gov/flu/pandemic-resources/1918-pandemic-h1n1.html (terakhir diakses 23 September 2020 pukul 21.00).

Direktorat Riset dan Pengabdian Masyarakat Kemenristekdikti. 2020. Panduan Penelitian dan Pengabdian kepada Masyarakat Edisi XIII Tahun 2020.

Peraturan Menteri Pendidikan dan Kebudayaan No. 3 Tahun 2020 tentang Standar Nasional Pendidikan Tinggi.

Republika (edisi 10 Agustus 2020). Mendikbud: Perguruan Tinggi Garda Depan Penanganan Covid-19. Website: https://republika.co.id/berita/qeunjj423/mendikbud-perguruan-tinggigarda-depan-penanganan-covid-19

Satuan Tugas Penanganan Covid-19 Republik Indonesia. Data Sebaran. Website: https://covid19.go.id/ (data 23/9/2020, 21.00) (terakhir diakses 23 September 2020 pukul 21.00)

Undang-undang No. 12 Tahun 2012 tentang Pendidikan Tinggi.

World Health Organization (WHO). Data Coronavirus Disease (Covid-19) Pandemic. Website: https://www.who.int/emergencies/diseases/novel-coronavirus-2019 (terakhir diakses 23 September 2020 pukul 21.00) 